DOI: https://doi.org/10.24867/13CG09Vujinovic

\title{
ПРИМЕНА RONЕТ МОДЕЛА НА МРЕЖИ ДРЖАВНИХ ПУТЕВА РЕПУБЛИКЕ СРБИЈЕ
}

\section{APPLICATION OF RONET MODEL ON THE STATE ROAD NETWORK OF THE REPUBLIC SERBIA}

\author{
Сузана Вујиновић, Небојша Радовић, Факултет техничких наука, Нови Сад
}

\section{Област- ГРАЂЕВИНАРСТВО}

Кратак садржај - RONET (Road Network Evaluation Tools) модел представьва управљачки алат, финансиран од стране SSATP и Светске Банке. Помаже доносиочима одлука јер проценује тренутно стање мреже, ьен релативни значај за економију и прорачунава скуп индикатора праћења за прочену перформанси путне мреже. Најбитнији су квалитетни подаци, које проверавају надлежне агениије за путеве. Они омогућавају већу тачност и прецизност система за управљање коловозом,као и стицање поверења у податаке и анализе. Резултати RONET модела показују важност сталне подршке иницијативама за одржавање путева. Улагање у путну инфраструктуру има развојни значај, јер подстиче привредне токове. Радови на одржавању проистичу из потребе да пут одговара намени због које је граћен, да омогући безбедно одвијање саобраћаја, транспорт људи и материјалних добара.

Кључне речи: Путна нфраструктура, Ронет модел, Управљање путном мрежом

\begin{abstract}
The RONET (Road Network Evaluation Tools) model is a management tool, funded by SSATP and the World Bank. It helps decision makers because it assesses the current state of the network, its relative importance to the economy and calculates a set of monitoring indicators to assess the performance of the road network. The most important are quality data, which are checked by the competent road agencies. They enable greater accuracy and precision of the road management system, as well as gaining trust in data and analysis.. The results of the RONET model show the importance of ongoing support for road maintenance initiatives. Investing in road infrastructure has development significance because it stimulates economic flows. Maintenance works results from the need for the road to correspond to the purpose for which it was built, to enable safe traffic, transport of people and material goods
\end{abstract}

Key words: Road infrastructure, Ronet model, Road network management

\section{НАПОМЕНА:}

Овај рад проистекао је из мастер рада чији ментор је био проф. др Небојша Радовић дипл. инж. грађ).

\section{1. УВОД}

Стање путне мреже утиче на све становнике без обзира на њихов финансијски положај, јер утиче на развој читаве земње. Примена одговарајућег рутинског и периодичног одржавања на правилан и благовремен начин резултирала би прихватљивим нивоом услуге до тренутка када се достигне оптерећење конструкцијског дизајна.

Многи путеви заправо знатно премашују ову тачку пре него што захтевају веће структурне поправке. Неадекватно одржавање доводи до прераног пропадања путне мреже.

\section{1 Путна мрежа у Србији}

Државни путеви су јавни путеви којима се повезује простор државе са мрежом европских путева, простор државе са мрежом најважнијих путева суседних земаља и простор унутар себе, кроз повезивање значајних насеља. Изградња, осавремењивање и одржавање путева спада под надлежност републичког тј. покрајинског нивоа. Укупна дужина путне мреже у Републици Србији износи 42.692 км, од тога $16.844,287$ км чине државни путеви.

Путну мрежу сачињавају државни путеви првог и другог реда.

Државни путеви I реда - саобраћајно повезују територију државе и повезују државу са мрежом европских путева:

$$
\begin{aligned}
& \text { 1.I A - } 962.340 \mathrm{~km} \\
& \text { 2.I Б - } 4.516,760 \mathrm{~km}
\end{aligned}
$$

Државни путеви II реда - саобраћајно повезују подручје два или више управна округа или подручје управног округа, погранична и туристичка подручја и граничне прелазе са мрежом државних путева:

1.II A $-7.903,081 \mathrm{~km}$

2.II Б - 3.462,106 km

Мрежом државних путева I и II реда управља Јавно предузеће „Путеви Србије“.

\section{2. ПРИМЕНА RONЕТ МОДЕЛА НА МРЕЖИ ДРЖАВНИХ ПУТЕВА РЕПУБЛИКЕ СРБИЈЕ}

\section{1 Улазни подаци}

Улазни подаци укључују:

1. Назив земље и година; 
2. Површина земљишта, укупна популација, рурална популација, БДП, укупан возни парк, дисконтна стопа, стопа раста саобраћаја.

3. Капитални трошкови за рад на путу

Статистика мреже:

1. Дужина и искоришћеност пута

2. Вредност имовине

3. Храпавост

4. Дистрибуција мреже

Индикатори праћења:
1. Густина мреже
2. Стање мреже
3. Стандарди мреже
4.Умрежавање

\subsection{1 Прикупљање података}

За управљање путевима користе се различите врсте података. Технологије за прикупљање података и потребе за подацима варирају у зависности од тога који се елемент инфраструктуре процењује.

Прикупљање података представља један од четири корака система за управљање коловозима. Подаци описују физичке елементе путног система, за које се може очекивати да ће се временом променити.

Прекомерно прикупљање података вероватно је један од пет главних разлога због којих се напуштају системи управљања путевима (РМС). На системе се гледа као на превише податковно интензивно и прескупо за одржавање.

Подаци који су коришћени у овом раду прикупљани су током 2019. и 2020. године. Скупљани су подаци о инвентару и стању путне мреже, након обраде података извршена је њихова верификација и уношење у Базу Података о Путевима.

\subsection{2 Подаци о земљи}

Република Србија се налази у југоисточној Европи и у средњој Европи. Главни град РС је Београд.

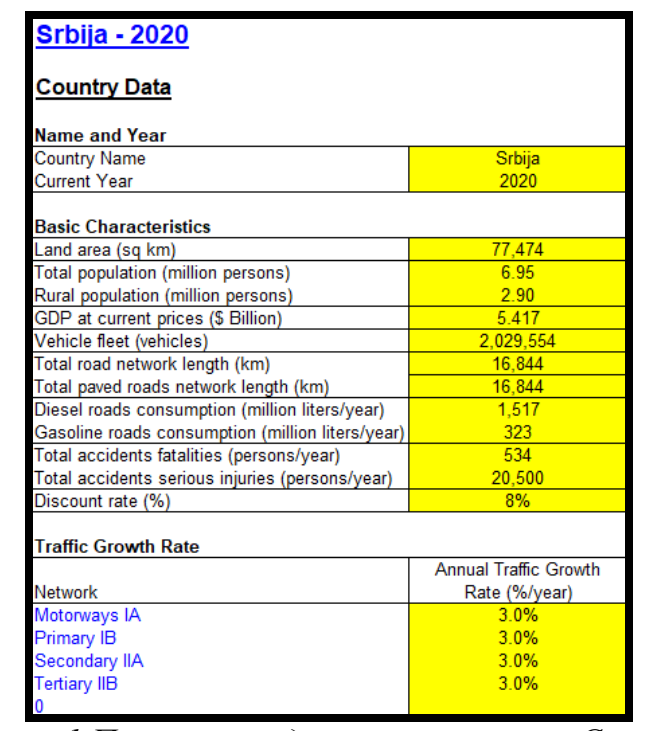

Слика 1.Попуњени подацчи на страниции „, Country data"
Убраја се у медитеранске земље, преовлађује умерено континентална клима. Према класификацији влажности припадамо умерено сувом типу.

Средње месечне падавине износе су $56 \mathrm{~mm}$. За потребе израде рада процењена стопа раста саобраћаја $3 \%$.

\subsection{2 Дужина путне мреже}

Дужина путне мреже државних путева који ће бити обрађени у RONET моделу, за мрежу IB износи $3.979,736 \mathrm{~km}$ укупно 549 деоница, а за мрежу IA износи 1.805,846 km, укупно 200 деоница.

Укупна дужина путне мреже мора бити позната, на основу те информације RONET дефинише колико је потребно путном сектору на основу јединичне цене по километру. На основу тога доносиоци одлуке израђују планове и распоређују ресурсе.

Укупна дужина путне мреже државних путева по појединим категоријама је сведена на еквивалентну ширину двотрачног пута од $7.2 \mathrm{~m}$.

\subsection{3 Историјски издаци}

Подаци се уносе према врсти мреже, врсти радова на путу (рехабилитација, периодично одржавање, рутинско одржавање) и типу површине (асфалтирана/неасфалтирана).

RONET модел прорачунава одговарајуће просечне издатке за радове на путу током последњих пет година, за различите врсте радова на путевима и типу површина.

\subsection{4 Трошкови корисника путева}

За $820 \mathrm{~km}$ аутопутева који су под наплатом,наплата се обавља преко аутоматског техничког система који се састоји од 65 наплатних станица. Основица за путарину је дужина релације јавног пута коју возило прелази у km. Цена путарине се одређује према три критекријума:

1. Цена путарине по километру

2. Категорији возила

3. Дужини пређене релације

У Републици Србији омогућена су два типа наплате путарина:

1. Систем плаћања мануелним путем - преузимамо магнетну картицу, приликом укључивања у систем наплате путарине, на крају пута предајемо магнетну картицу на наплатној станици и на основу ње плаћамо путарину

2. Систем електронског плаћања - безконтактни модел плаћања - користимо пролаз који је означен ЕНП, без заустављања и преузимања магнетне картице.

\section{2 Излазни подаци}

Излазни подаци RONET модела процењују тренутно стање путне мреже и представљају резиме мрежне статистике и индикатора надгледања путне мреже. 
Дужина и употреба: представља укупну дужину мреже и дистрибуцију коришћења мреже према типу мреже и типу површине.

Вредност имовине: представља максималну вредност имовине и расподелу тренутне вредности имовине по типу мреже и типу површине.

\section{ИРИ: представља просечну равност мреже.}

Мрежни дистрибуциони графици: представљају мрежне дистрибуцијске графиконе дужине мреже, искоришћености и максималну и тренутну вредност имовине према типу мреже и типу површине.

Сви резултати се рачунају помоћу Excell формула, из тог разлога не постоји одређено дугме за притискање за израчунавање.

Резултати се аутоматски прерачунавају када променимо било који податак о конфигурацији или улазне податке.

Излазне странице садрже табеле и графиконе и форматиране су за штампу.

\subsection{1 Дужина и употреба}

Излазни подаци који представљају укупну дужину мреже $(\mathrm{km})$ и укупну искоришћеност мреже (милион возила- km) и дистрибуцију према:

-Типу мреже

•Типу површине

-Класи површине

-Категорија саобраћаја.

Можемо да бирамо имеђу:

•Дистрибуција према типу мреже

-Расподела према типу површине

-Расподела према класи површине

Када одаберемо опцију, можемо видити одговарајућу расподелу према типу површине, стању на путу и категоријама саобраћаја. Табеле дужине мреже налазе се на десној страни.

\subsection{2 Опште добро}

Опште добро представља пропорционалан удео економије.

Дели се према према типу мреже,типу пута,категорији стањапутаи саобраћају.

На врху странице налази се садржај где можемо бирати између дистрибуције према типу мреже, расподеле према типу површине, расподеле према површинској класи.

Када одаберемо опцију, можемо да видимо одговарајућу расподелу према типу површине, категорији стања пута и категорији саобраћаја. Табеле максималне вредности имовине налазе се на десној страни и табеле вредности тренутне имовине са леве стране.

Вредност имовине прорачунавамо тако што сваку класу пута, дужине класе пута множимо са трошковима нове грађевинске јединице одговарајућег типа површине, која је унета на страници „Подаци о земљи“.
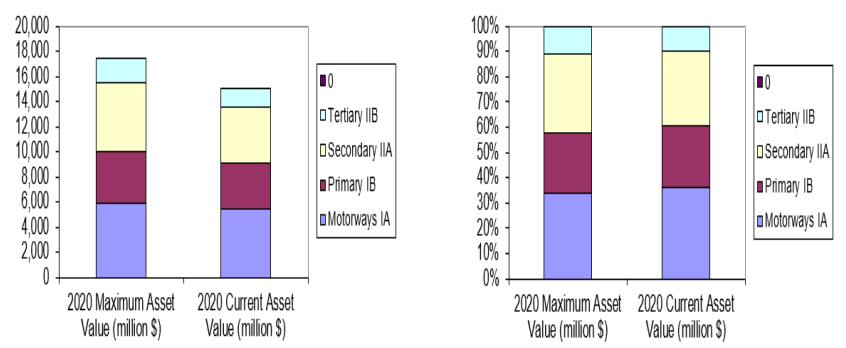

Слика 2. Максимална вредност и тренутна вредност према типу повриине, стағу пута и саобраћају

\subsection{3 ИРИ}

Равност је индикатор који има највећи значај за кориснике путева:

1. Утиче на трошкове корисника пута - већа неравност има за последицу оштећење возила;

2. Повећава време путовања корисник успорава вожњу да би смањио неугодност због неравномерног пута;

Међународни индекс храпавости - ИРИ - општи показатељ стања коловоза који се изражава у m/ $\mathrm{km}$. Представља суму амплитуда, укупних вертикалних померања возила по $1 \mathrm{~km}$ пута. Модел је заснован на симулацији четвртине аутомобила.

\section{International Roughness Index}

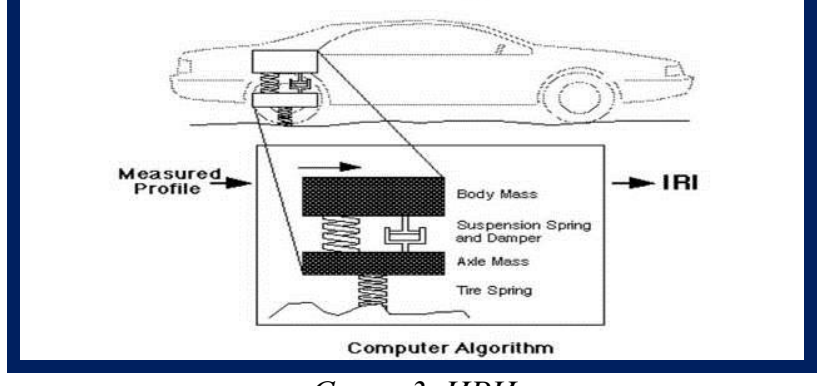

Слика 3. ИРИ

\section{2. ПРЕДНОСТИ И НЕДОСТАТЦИ RONЕT МОДЕЛА}

\section{Предности:}

Ронет модел је, у суштини, прорачунска табела Ms Excel, из тог разлога је врло једноставан за употребу, а време за анализу изузетно кратко. Обезбеђује велику количину информација доносиоцима одлука него што је то било раније. Улазни подаци су лако доступни, из извештаја о буџету, студија изводљивости, алата Светске Банке. Излазни подаци су веродостојни, испуњаваће услобе буџета организацијама задуженим за путеве;

\section{Недостаци:}

Укупни подаци су веома подложни грешкама. Ажурирани подаци о промету и стању за секундарне и терцијарне мреже обично нису доступни. Модел још увек не спроводи оптимизацију стандарда. Утицај на 
преоптерећење потреба мреже не може се лако моделирати још увек. Није лако прикупити све податке које често захтевају и израду мањих студија. Није погодан за земље где су издавања за путева из накнада за кориснике путева (таксе и издвајања из продајне цене горива) мала, као у случају Републике Србије.

\section{5. ЗАКЉУЧАК}

RONET модел представља покушај стварања једноставног модела за решавање проблема одсуства једноставних аналитичких модела, јер се често дешавало да организације за путеве не могу на прави начин приказатисвоје потребе пред политичарима и финансијским донаторима.

Не врши оптимизацију стандарда, и конкретно за Републику Србију није погодан јер су издавања за путева из накнада за кориснике путева (таксе и издвајања из продајне цене горива) мала.

Путне организације могу да користе RONET за планирање пројеката одржавања и рехабилитације будући да ће знати тачну брзину погоршања њихове мреже и колики је промет на мрежи, и колика је вредност имовине.

Модел је још увек у фази израде и до садасу добијени резултати за „бета тестирање““.

Развој модела финансира SSATP и Светска Банка.

Анализа за мрежу државних путева Републике Србије je показала да је недовољно актуелно финансирање путне мреже у односу на потребна улагања.

\section{Comparison of Road Fund Revenues and Funding Requirements}

\begin{tabular}{|c|c|c|c|}
\hline $\begin{array}{c}\text { Actual } \\
\text { Revenues } \\
\text { (M\$/year) }\end{array}$ & $\begin{array}{c}\text { Estimated } \\
\text { Needs } \\
\text { (M\$/year) }\end{array}$ & $\begin{array}{c}\text { Gap } \\
\text { (M\$/year) }\end{array}$ & $\begin{array}{c}\text { Gap } \\
(\%)\end{array}$ \\
\hline 385.38 & $2,408.72$ & $2,023.33$ & $84 \%$ \\
\hline
\end{tabular}

Слика 4. Поређење захтева и прихода

\section{6. ЛИТЕРАТУРА}

[1] Радовић, Н., Шешлија,М.: У прављање путном мрежом, Прво издање, Факултет техничких наука, Нови Сад, 2017.

[2] Узелац, Ђ.: Коловозне конструкције,ФТН Издаваштво, Нови Сад, (2015).

[3] Mosianedi, J.T: Pavement management analysis using RONET: Case of the Free State province, 2016.

[4] Ћириловић, Ј., Младеновић, Г., Queiroz, C.: Impact of $\mathrm{CO} 2$ emissions on low volume road maintenance policy - Case stady of Serbia, 2019

[5] Закон о путевима (“Службени гласник РС”, бр. $41 / 2018$ и 95/2018).

\section{Кратка биографија:}

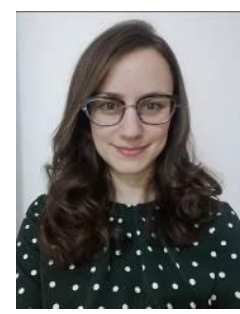

Сузана Вујиновић рођена у Санском Мосту 15.02.1991. год. Гимназију „Исидора Секулић" у Новом Саду завршава 2010. године, и исте године уписује студије грађевинарства на Факултету техничких наука, Универзитета Нови Сад. Звање дипломираног инжењера грађевинарства стиче 2019. године. Мастер рад на одсеку за путеве, железнице и аеродроме са темом Примена RONET модела на мрежи државних путева Републике Србије одбранила је 2020. године.

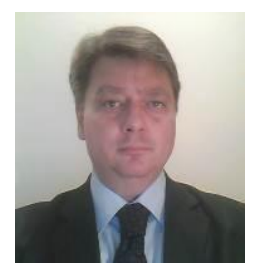

Небојша Радовић рођен је у Београду, 1962. год. Докторирао је на Факултету техничких наука Универзитета у Новом Саду 2006. год., а од 2020. год. је редован професор на Факултету Техничких Наука Универзитетс у Новом Саду. Област интересовања су путеви и саобраћајнице. 